\title{
Aberrant expression and regulation of NR2F2 and CTNNB1 in uterine fibroids
}

\author{
Marina Zaitseva, Sarah J Holdsworth-Carson, Luke Waldrip', Julia Nevzorova, \\ Luciano Martelotto ${ }^{2}$, Beverley J Vollenhoven ${ }^{1,3}$ and Peter A W Rogers
}

Department of Obstetrics and Gynaecology, Royal Women's Hospital, University of Melbourne, Level 7, 20 Flemington Road, Parkville, Victoria 3052, Australia, ${ }^{1}$ Department of Obstetrics and Gynaecology, Monash Medical Centre, Monash University, 246 Clayton Road, Clayton, Victoria 3168, Australia, ${ }^{2}$ Department of Pathology, Memorial Sloan-Kettering Cancer Center, Memorial Hospital, 1275 York Avenue, New York, New York 10065, USA and ${ }^{3}$ Monash Institute of Medical Research, Monash University, 27-31 Wright Street, Clayton, Victoria 3168, Australia

Correspondence should be addressed to P A W Rogers; Email: parogers@unimelb.edu.au

\begin{abstract}
Uterine fibroids are the most common benign tumour afflicting women of reproductive age. Despite the large healthcare burden caused by fibroids, there is only limited understanding of the molecular mechanisms that drive fibroid pathophysiology. Although a large number of genes are differentially expressed in fibroids compared with myometrium, it is likely that most of these differences are a consequence of the fibroid presence and are not causal. The aim of this study was to investigate the expression and regulation of NR2F2 and CTNNB1 based on their potential causal role in uterine fibroid pathophysiology. We used real-time quantitative RT-PCR, western blotting and immunohistochemistry to describe the expression of NR2F2 and CTNNB1 in matched human uterine fibroid and myometrial tissues. Primary myometrial and fibroid smooth muscle cell cultures were treated with progesterone and/or retinoic acid (RA) and sonic hedgehog $(\mathrm{SHH})$ conditioned media to investigate regulatory pathways for these proteins. We showed that NR2F2 and CTNNB1 are aberrantly expressed in fibroid tissue compared with matched myometrium, with strong blood vessel-specific localisation. Although the SHH pathway was shown to be active in myometrial and fibroid primary cultures, it did not regulate NR2F2 or CTNNB1 mRNA expression. However, progesterone and RA combined regulated NR2F2 mRNA, but not CTNNB1, in myometrial but not fibroid primary cultures. In conclusion, we demonstrate aberrant expression and regulation of NR2F2 and CTNNB1 in uterine fibroids compared with normal myometrium, consistent with the hypothesis that these factors may play a causal role uterine fibroid development.
\end{abstract}

Reproduction (2013) 146 91-102

\section{Introduction}

Uterine fibroids, or leiomyoma, are the most common benign tumour afflicting women of reproductive age (Okolo 2008, Wechter et al. 2011). While many women with uterine fibroids are asymptomatic, $35-50 \%$ of women experience fibroid-related symptoms, including heavy, painful periods, anaemia, frequent urination, abdominal swelling, pressure pains and pregnancy complications (Day Baird et al. 2003). Currently, uterine fibroids are the single-most common reason for hysterectomy in developed countries (Treloar et al. 1999, Farquhar \& Steiner 2002, Garry 2005), and despite their large healthcare burden, there is limited understanding of the molecular mechanisms that drive fibroid pathophysiology. Gene profiling studies by our laboratory and others have identified a large number of genes with altered expression in fibroid tumours compared with myometrium (Tsibris et al. 2002, Skubitz \& Skubitz 2003,
Arslan et al. 2005, Luo et al. 2005a, 2005b, Zaitseva et al. 2006, Dimitrova et al. 2009). However, it is hypothesised that the majority of these genes are differentially expressed as a consequence of the changed microenvironment caused by the fibroids' presence and are not causal to fibroid development.

This study focuses on two genes: CTNNB1 ( $\beta$-catenin) and chicken ovalbumin upstream promoter transcription factor II (COUP-TFII, known as NR2F2). Our previous studies report that CTNNB1 mRNA expression is increased in fibroids; conversely, NR2F2 mRNA is decreased in association with fibroids (Zaitseva et al. 2006, 2008). Importantly, circumstantial evidence exists, which supports a potential causal role for NR2F2 and CTNNB1 in fibroid development. CTNNB1 plays a structural role in cadherin junction cell-cell adhesion and is also an essential transcriptional co-activator component of the canonical Wnt signalling pathway. In uterine biology, CTNNB1 plays roles in menstruation 
(Nei et al. 1999) and implantation (Mohamed et al. 2005, Jeong et al. 2009) and has been linked to endometrial hyperplasia and cancer (Fukuchi et al. 1998, Nei et al. 1999, Jeong \& McMahon 2005). Suggestive of a causative role in uterine fibroid development is the observation that sustained Ctnnb1 expression in transgenic mice results in uterine mesenchymal tumours, which are histologically similar to human uterine leiomyoma (Tanwar et al. 2009). $N R 2 F 2$ belongs to the steroid/thyroid hormone receptor superfamily and plays important roles in development, including cell differentiation, cell cycle and migration, and angiogenesis (see review Boudot et al. (2011)). It has been suggested that $N R 2 F 2$ has a role in cancer development and epithelial-mesenchymal-transition (EMT; Boudot et al. 2011). NR2F2 is expressed in the endometrium and myometrium (Chu et al. 1998, Takamoto et al. 2005) where it is involved in regulation of implantation/decidualisation (Takamoto et al. 2005, Kurihara et al. 2007, Lee et al. 2010) and placentation (Petit et al. 2007, Hubert et al. 2010). Conditional knockout of $\mathrm{Nr} 2 \mathrm{f} 2$ in mouse uteri results in stunted uterine growth and disorganised myometrial smooth muscle layers (Petit et al. 2007). Therefore, based on this cumulative evidence, the first aim of this study was to more fully define the expression profiles and localisation of CTNNB1 and NR2F2 in human uterine fibroid and myometrial tissues.

CTNNB1 and NR2F2 share many common regulatory factors; with particular relevance to uterine fibroids are retinoic acid (RA), progesterone and sonic hedgehog $(\mathrm{SHH})$ ligands. RA has implications in uterine fibroid pathology (Arslan et al. 2005, Zaitseva et al. 2007), and CTNNB1 is a RA-responsive gene (Byers et al. 1996). By interacting with $R A$ receptor (RAR) and retinoid $X$ receptor $(R X R), N R 2 F 2$ negatively regulates $R A$ signalling (reviewed by Boudot et al. (2011)). Progesterone regulates Wnt/CTNNB1 signalling in the uterus via the Wnt inhibitor Dickkopf-1 (DKK1; Tulac et al. 2006, Wang et al. 2010). Acting through its receptor (PR), progesterone increases uterine expression of $\mathrm{HH}$ protein, which in turn regulates NR2F2 expression (Lee et al. 2006b, Kurihara et al. 2007, Simon et al. 2009a). HH is crucial to normal and abnormal uterine (and endometrial) development and is also regulated by progesterone (Feng et al. 2007, Kim et al. 2009, Wei et al. 2010, Franco \& Yao 2012). Currently, however, data are lacking on the potential roles of progesterone, $\mathrm{RA}$ and/or $\mathrm{SHH}$ regulatory molecules in controlling CTNNB1 and/or NR2F2 in human myometrium and fibroid tissues. Thus, the second aim of this study was to investigate in vitro regulation of CTNNB1 and NR2F2 in human myometrial and fibroid primary cells by progesterone, $\mathrm{RA}$ and $\mathrm{SHH}$.

Epidemiological data shows that uterine fibroids are one of the most significant gynaecological conditions affecting reproductive-aged women today
(Wechter et al. 2011). We hypothesise that CTNNB1 and $N R 2 F 2$ have causal roles in the development of uterine fibroids. This study investigated the expression and regulation of CTNNB1 and NR2F2 in uterine fibroids and myometrium with the overall goal to achieve a better understanding of the molecular mechanisms that drive fibroid initiation and growth.

\section{Materials and Methods}

\section{Tissue collection}

Human myometrial and fibroid tissues were obtained from premenopausal women who had not been on hormonal therapy for at least 3 months before collection and were undergoing hysterectomy for fibroids ( $n=57$, mean age 46.4 , range $35-56$ years). Informed consent was obtained from each patient with approval from the Royal Women's Hospital Human Research Ethics Committee or Monash Medical Centre Human Research Ethics Committee. Detailed clinical menstrual history was obtained at the time of consent and cycle stage was confirmed by pathology (Noyes et al. 1950). Patient endometrium was classified as proliferative $(n=31)$, secretory $(n=23)$ or inactive $(n=2)$. Normal myometrium was taken at least $2 \mathrm{~cm}$ from adjacent fibroid tissue. When more than one fibroid was identified in a uterus, a sample was taken from the body of the largest fibroid. Patients were not stratified according to fibroid location (subserosal, submucosal or intramural); however, degenerative-type fibroids (hyaline, calcification, cystic or red (hemorrhagic)) were excluded from the study. Myometrial and fibroid tissues were immediately snap frozen and stored at $-80{ }^{\circ} \mathrm{C}$, fixed in formalin or collected in HEPES-buffered M199culture medium with $10 \%$ (v/v) FCS and antibiotic-antimycotic liquid (all reagents from Life Technologies) and stored overnight at $4{ }^{\circ} \mathrm{C}$ before being processed for primary cell culture.

\section{RNA extraction and RT-qPCR}

RNA was extracted from primary cells or frozen tissue $(n=10$ proliferative and $n=10$ secretory myometrial and fibroid pairs) in $1 \mathrm{ml} \mathrm{TRIzol}$ reagent followed by DNase treatment as per manufacturer's instructions (both from Life Technologies). Frozen tissue samples were homogenised using a PowerLyzer 24 bench top bead-based homogeniser for $3 \times 35 \mathrm{~s}$ bursts $(\mathrm{MO}$ BIO Laboratories, Inc., Carlsbad, CA, USA). RNA was ethanol precipitated, resuspended in RNase-free water and stored at $-80^{\circ} \mathrm{C}$. Concentration and quality of RNA was assessed with a Nanodrop u.v. spectrophotometer (Thermo Fisher Scientific, Scoresby, VIC, Australia) using an absorbance ratio of 260:280 nM ( $\left.\mathrm{A}_{260: 280}\right)$.

RNA was converted to cDNA using High Capacity cDNA RT Kit with RNase inhibitor according to the manufacturer's instructions (Life Technologies). Briefly, $1 \mu \mathrm{g}$ total RNA was incubated with $4 \mathrm{mM}$ dNTPs, $2 \mu \mathrm{l}$ random primers, $2 \mu \mathrm{l} 10 \times$ RT buffer, $20 \cup$ RNase inhibitor and $50 \cup$ MultiScribe Reverse Transcriptase for $10 \mathrm{~min}$ at $25^{\circ} \mathrm{C}$, followed by $120 \mathrm{~min}$ at $37^{\circ} \mathrm{C}$ and $5 \mathrm{~min}$ at $85^{\circ} \mathrm{C}$ in $20 \mu \mathrm{l}$ volume. All RT-qPCR experiments were performed using a LightCycler 480 real-time PCR machine (Roche), LightCycler 480 Probe Master (Roche) 
using TaqMan (Life Technologies) or Universal Probe (Roche) assays (see Table 1 for primer details). Relative quantification was performed using the $2^{-\Delta \Delta C t}$ method (Livak \& Schmittgen 2001), with $18 S$ rRNA used as an endogenous control to correct for differences in concentration of the starting template.

\section{Protein extraction and western blotting}

Whole cell protein was extracted from frozen myometrium and fibroid tissue $(n=10$ proliferative and $n=10$ secretory myometrial and fibroid pairs) via homogenisation in RIPA buffer plus phosphatase inhibitor cocktail 2 (1:200 dilution) and protease inhibitor cocktail (1:1000 dilution) (all from Sigma-Aldrich). Tissue homogenisation conditions are same as described earlier. Protein concentrations were determined using the Pierce BCA Protein Assay following the manufacturer's instructions (Thermo Fisher Scientific).

Protein samples $(20 \mu \mathrm{g})$ were resolved on $10 \%$ NuPAGE BisTris polyacrylamide gels (Life Technologies) at $150 \mathrm{~V}$ for $60 \mathrm{~min}$ and transferred onto nitrocellulose membrane (Bio-Rad Laboratories) at $30 \mathrm{~V}$ for $60 \mathrm{~min}$ using Life Technologies's XCell II blot module. Membranes were blocked with 5\% (w/v) skim milk powder in Tris-buffered saline plus $0.1 \% \mathrm{v} / \mathrm{v}$ Tween 20 (TBS-T) for $1 \mathrm{~h}$ at RT. Primary antibody incubations occurred at $4{ }^{\circ} \mathrm{C}$ overnight in $2 \%(\mathrm{w} / \mathrm{v})$ skim milk powder in TBS-T. Dilutions were 1:1000 for mouse monoclonal anti-NR2F2 (Clone H7147) (Abcam, Cambridge, UK) and mouse monoclonal anti-CTNNB1 (Clone 14; BD Biosciences, Sparks, MD, USA) and 1:10 000 for mouse monoclonal anti- $\beta$-actin (SigmaAldrich). HRP-conjugated goat anti-mouse secondary antibody (Life Technologies) was diluted 1:4000 for NR2F2 and CTNNB1 blots and 1:7500 for $\beta$-actin blots in $2 \%(\mathrm{w} / \mathrm{v})$ skim milk powder in TBS-T and incubated for $1 \mathrm{~h}$ at RT. ECL Prime Western blotting detection reagent (GE Healthcare, Uppsala, Sweden) was for signal detection and was captured using an ImageQuant LAS 4000 (GE Healthcare). Densitometry values were measured using Multi Gauge V3.0 Software (Fujifilm, Brookvale, NSW, Australia). Protein molecular weight marker, SeeBlue Plus2 (Life Technologies), was loaded $(5 \mu \mathrm{l} /$ gel) in order to determine band molecular weights. $\beta$-Actin was detected at $42 \mathrm{kDa}, \mathrm{NR} 2 \mathrm{~F} 2$ at $46 \mathrm{kDa}$ and native CTNNB1 at $85 \mathrm{kDa}$. CTNNB1 degradation products were also detected between 70 and $55 \mathrm{kDa}$ (Tesco et al. 1998). NR2F2 and

Table 1 Primer sequences for RT-qPCR.

\begin{tabular}{|c|c|c|}
\hline Gene & Primer sequence & $\begin{array}{l}\text { TaqMan assay/UPL } \\
\text { probe }\end{array}$ \\
\hline$N R 2 F 2$ & NA & $\begin{array}{l}\text { TaqMan } \\
\text { HS01047078_ml }\end{array}$ \\
\hline CTNNB1 & $\begin{array}{l}5^{\prime} \text {-gcagagtgctgaaggtgcta- } 3^{\prime} \\
5^{\prime} \text {-tctgtcaggtgaagtcctaaagc-3 }\end{array}$ & UPL \#31 \\
\hline PTCH1 & $\begin{array}{l}5^{\prime} \text {-aggatacaaccccaatgcag-3' } \\
5^{\prime} \text {-caggctcttgaacctctgga- } 3^{\prime}\end{array}$ & UPL \#15 \\
\hline GLI1 & $\begin{array}{l}5^{\prime} \text {-ggattaaaagcagcgaacctc-3' } \\
5^{\prime} \text {-cacgacttactcgtcctccaa-3' }\end{array}$ & UPL \#17 \\
\hline$P R$ & $\begin{array}{l}5^{\prime} \text {-tttaagagggcaatggaagg- } 3^{\prime} \\
5^{\prime} \text {-cggattttatcaacgatgcag-3' }\end{array}$ & UPL \#11 \\
\hline $18 S$ & $\mathrm{NA}$ & $\begin{array}{l}\text { TaqMan eukaryotic } \\
18 S \text { rRNA endogen- } \\
\text { ous control }\end{array}$ \\
\hline
\end{tabular}

CTNNB1 immunoblots were normalised using $\beta$-actin with values displayed as mean optical densities $\left(\mathrm{OD} / \mathrm{mm}^{2}\right)$.

\section{Immunohistochemistry}

Paraffin-embedded myometrial and fibroid tissues $(n=10$ proliferative and $n=10$ secretory myometrial and fibroid pairs) were cut into $3 \mu \mathrm{m}$ sections, mounted on saline-coated slides, dewaxed and dehydrated. Sections underwent antigen retrieval (boiling citrate buffer $(\mathrm{pH}$ 6.0) for $15 \mathrm{~min}$ ) and endogenous peroxidases were blocked with $3 \%(v / v) \mathrm{H}_{2} \mathrm{O}_{2}$ in methanol (10 min at RT). Sections were blocked with serumfree protein block (Dako, Glostrup, Denmark; 10 min at RT) and incubated with mouse monoclonal NR2F2 Clone H7147 $(2 \mu \mathrm{g} / \mathrm{ml})$ (Abcam) or mouse monoclonal CTNNB1 Clone 14 $\left(0.5 \mu \mathrm{g} / \mathrm{ml}\right.$; BD Biosciences) overnight at $4{ }^{\circ} \mathrm{C}$. Mouse IgG1 or IgG2a (Dako) at equivalent concentrations were used as negative controls. Sections were incubated with mouse EnVision + System-HRP (Dako) (30 min at RT) followed by 3,3'-diaminobenzidine (Sigma-Aldrich) for $5 \mathrm{~min}$ at RT. Sections were counterstained with Harris haematoxylin (Amber Scientific, Midvale, WA, Australia).

Double IHC was performed for NR2F2/CTNNB1 and for NR2F2 or CTNNB1 with vimentin, $\alpha$ SMA and CD31. Dewaxed and rehydrated sections were first incubated overnight at $4{ }^{\circ} \mathrm{C}$ with mouse anti-human vimentin clone $\mathrm{V} 9(0.14 \mu \mathrm{g} / \mathrm{ml}$; Life Technologies), mouse anti-human $\alpha \mathrm{SMA}(0.0875 \mu \mathrm{g} / \mathrm{ml}$; Dako $)$ and mouse anti-human CD31 clone JC70A (0.86 $\mu \mathrm{g} / \mathrm{ml}$; Dako). Mouse IgG (Dako) at equivalent concentrations was used as a negative control for each step. For CD31 only, sections underwent antigen retrieval (as described earlier) immediately following dewaxing and rehydration. Sections were incubated with LSAB + alkaline phosphatase kit, as per the manufacturer's instructions (Dako), followed by visualisation with vector blue (Vector Laboratories, Burlingame, CA, USA). Immunostaining for either NR2F2 or CTNNB1 followed (as described earlier). For NR2F2/CTNNB1 double IHC, NR2F2 staining preceded CTNNB1 staining. No counterstaining was used for double IHC.

Slides were mounted with aqueous mounting media (Dako). Images were observed using a Zeiss Axioskop light microscope, AxioCam ICc 3 Zeiss camera and AxioVision System Software (release 4.6; Carl Zeiss Imaging Solutions, Munchen, Germany). Immunostaining for NR2F2 and CTNNB1 was semiquantitatively assessed in different tissue compartments (myometrium, myometrial blood vessels and fibroid and fibroid blood vessels) by three independent observers. At least four fields of view per sample were assessed. Staining was graded from 0 to 3 (with 0.5 increments), where 0 was no staining and 3 was an intense staining.

\section{Primary myometrial and fibroid culture}

Primary cultures of myometrium and fibroid SMC were established as described previously (Gargett et al. 2002, Zaitseva et al. 2006, 2008). Briefly, myometrial and fibroid tissues were finely chopped and dissociated with multiple rounds of collagenase type-2 (Worthington Biochemical Corp., Lakewood, NJ, USA) and DNase type-I (Worthington 
Biochemical Corp.), followed by a short trypsin digestion (Life Technologies) until single-cell suspensions were generated. Cells were seeded into six-well culture plates and grown to confluence ( $\sim 7$ days) in DMEM/10\% FCS/antibiotics culture media in the absence of exogenous hormones. All primary cell culture experiments were performed at $\mathrm{P} 0$.

\section{Progesterone and RA study}

To investigate the effect of progesterone and/or all-trans RA on NR2F2 and CTNNB1 mRNA expression, primary cultures of myometrial and fibroid SMC $(n=5)$ were grown to confluence and serum starved for $48 \mathrm{~h}$ in phenol red-free DMEM with $1 \%$ charcoal-stripped FCS (Ch-FCS; Sigma-Aldrich). Cells were treated with progesterone $(100 \mathrm{nM})$ and/or all-trans RA $(1 \mu \mathrm{M})$ (both from Sigma-Aldrich) or vehicle control (ethanol) in DMEM/1\% Ch-FCS and antibiotics for $24 \mathrm{~h}$ (Fahnenstich et al. 2003, Zaitseva et al. 2008). RA $(1 \mu \mathrm{M})$ has been shown to increase RA-responsive gene expression in myometrial and fibroid culture (Zaitseva et al. 2008). No cycle stage-associated differences were observed following culture and therefore women included in this study were from mixed cycle stage ( $n=3$ proliferative, $n=1$ secretory and $n=1$ inactive endometrium). Following treatment, cells were collected in TRIzol (Life Technologies) for RNA extraction.

\section{SHH study}

To investigate a role for $\mathrm{SHH}$ in $\mathrm{NR} 2 \mathrm{~F} 2$ and CTNNB1 regulation, primary cultures of myometrial and fibroid SMC $(n=6)$ were grown to confluence, serum-starved (as described earlier) and treated with $\mathrm{SHH}$ conditioned media $(\mathrm{CM})$ in DMEM $/ 1 \%$ FCS for $24 \mathrm{~h}$ (Park et al. 2011). SHH CM was prepared as described previously (Ingram et al. 2002, Hochman et al. 2006, Park et al. 2011). Briefly, media were collected from SHHN-923 cells, which were transfected to secrete active SHH (N-terminal domain) in a pMT21 (pSHH-N-PMT21) plasmid. Myometrial and fibroid control SMC were treated with CM collected from cells transfected with an empty vector. Following treatment, cells were collected in TRIzol (Life Technologies) for RNA extraction.

\section{Statistical analysis}

All data were analysed using Graph Pad Prism Software (version 5, GraphPad Software, La Jolla, CA, USA). All data were tested for Gaussian distribution using the D'Agostino and Pearson omnibus normality test. Based on the normality test, parametric (repeated measures ANOVA followed by Tukey's post hoc test or paired $t$-test) or non-parametric (Friedman test with post hoc Dunn's test or Wilcoxon's signed rank matched pairs test) tests were utilised.

\section{Results \\ NR2F2 is differentially expressed during the secretory phase}

We investigated NR2F2 mRNA in myometrium and fibroids using real-time quantitative RT-PCR (RT-qPCR).
In agreement with our previous microarray data (Zaitseva et al. 2006, 2008), NR2F2 mRNA was downregulated in fibroids compared with myometrium (Fig. 1i). The fibroid-associated reduction in NR2F2 mRNA was only observed in secretory stage of the menstrual cycle, not during the proliferative phase (Fig. 1i; $P=0.002$ ). Western blot analysis and immunohistochemistry (IHC) were undertaken to characterise expression and localisation of NR2F2 protein in myometrium and fibroids. Western blotting for NR2F2 detected a $45 \mathrm{kDa}$ band in myometrial and fibroid whole-tissue extracts; however, unlike our mRNA data, densitometry analysis found that there was no significant difference in NR2F2 protein expression (Fig. 1ii). In contrast, significant differences in protein expression were identified following NR2F2 IHC. NR2F2 protein was nuclear and was localised to myometrial and fibroid smooth muscle cells (SMC), perivascular cells, endothelial cells and connective tissue (Fig. 1iv). Semiquantitative scoring determined that significantly stronger NR2F2 immunostaining (approximately twofold increase) was found around blood vessels in both myometrium and fibroid tissues compared with SMC (Fig. 1iii; $P<0.01$ ). However, with respect to blood vessel staining, there was no difference between myometrium and fibroid tissue. Like NR2F2 mRNA, myometrial SMC displayed significantly stronger NR2F2 expression compared with fibroid SMC during the secretory phase (Fig. $1 \mathrm{iii} ; P<0.05$ ). In addition, NR2F2 immunostaining in secretory phase myometrial SMC was also significantly increased compared with myometrial SMC in the proliferative stage (Fig. 1iii; $P<0.001$ ). There was no difference in NR2F2 immunostaining between myometrial and fibroid SMC in the proliferative phase (Fig. 1 iii).

\section{CTNNB1 is differentially expressed during the proliferative and secretory phases of the menstrual cycle}

CTNNB1 expression was also examined using RT-qPCR, western blotting and IHC. CTNNB1 mRNA expression was elevated in fibroids compared with matched myometrium (Fig. 2i), confirming our previous findings (Zaitseva et al. 2006). More specifically, CTNNB1 mRNA expression was significantly increased in fibroid tissue compared with myometrium in the proliferative phase $(P=0.04)$ and compared with secretory-phase fibroid tissue $(P=0.02)$ (Fig. 2i). CTNNB1 mRNA was unchanged in the myometrium during the menstrual cycle. Western blotting for CTNNB1 detected several bands between 85 and $55 \mathrm{kDa}$ (Fig. 2ii). The $85 \mathrm{kDa}$ band represents the full-length native protein, while the smaller molecular weight bands represent degradation fragments (Tesco et al. 1998). CTNNB1 (85 kDa) expression was significantly elevated in fibroids compared with normal myometrium in the secretory 

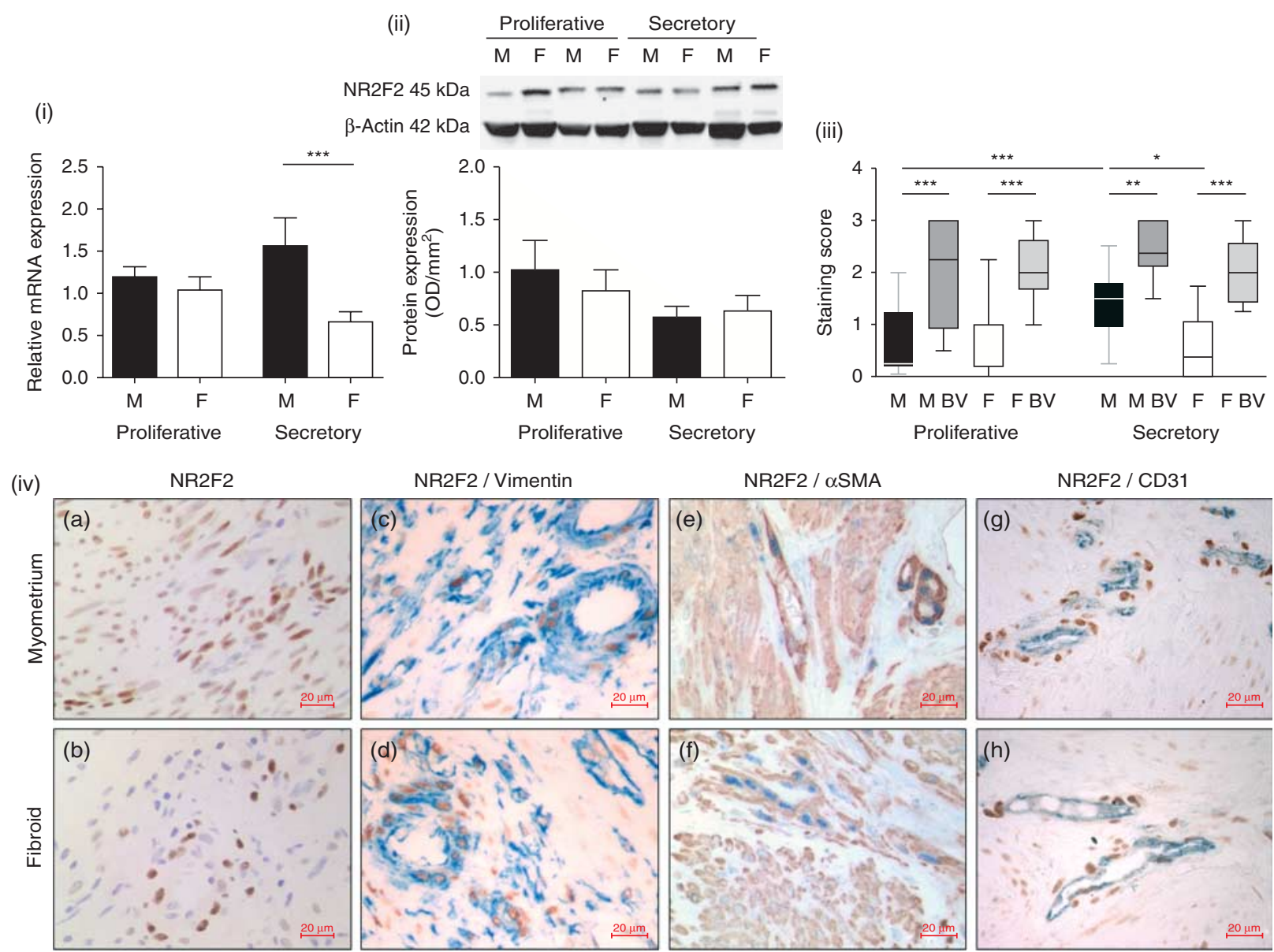

Figure 1 Differential NR2F2 expression in uterine myometrium and fibroids. Relative expression of NR2F2 mRNA (i) and protein (ii) in uterine fibroids (F) compared with matched normal myometrium (M) tissue. IHC (iv) for NR2F2 was performed on paired F and $M$ samples. M and $F$ were grouped according to proliferative and secretory phases of the menstrual cycle with $n=10$ paired $\mathrm{M}$ and $\mathrm{F}$ samples included per phase. IHC micrographs are representative only and do not depict cycle stage. Single NR2F2 myometrial (a) and fibroid (b) staining (brown). Double IHC for NR2F2 (brown) plus vimentin (Vim; blue) for M (c) and F (d), NR2F2 (blue) and aSMA (brown) for M (e) and F (f), and NR2F2 (brown) and CD31 (endothelial marker; blue) for $\mathrm{M}(\mathrm{g})$ and $\mathrm{F}(\mathrm{h})$. Note the distinctive strong NR2F2 staining in cells surrounding blood vessels. Scale bar $=20 \mu \mathrm{m}$. Semiquantitative scoring of NR2F2 protein staining intensity is displayed for M and F smooth muscle cells/stroma and also for MBV and FBV (iii). Scoring were performed on $n=10$ paired $M$ and $F$ samples from the proliferative phase and $n=12$ paired $M$ and $F$ samples from the secretory phases of the menstrual cycle. Relative protein expression of NR2F2 is displayed as the mean optical density $\left(\mathrm{OD} / \mathrm{mm}^{2}\right) \pm$ s.E.M. All other data are presented as the mean \pm S.E.M., with statistical difference denoted by ${ }^{* * *} P<0.001,{ }^{* *} P<0.01$ and $* P<0.05$.

phase of the menstrual cycle $(P<0.05 ;$ Fig. 2ii). Although CTNNB1 expression was higher in fibroids compared with myometrium during the proliferative phase, this failed to reach significance (Fig. 2ii).

CTNNB1 immunostaining was diffuse throughout the cytoplasm and cell surface, with weak to moderate intensity in myometrial and fibroid SMC (Fig. 2iv). Some nuclear staining was present in some cells. Similar to NR2F2, stronger staining was observed around some but not all blood vessels (Fig. 2iii and iv). CTNNB1 vascular staining was associated with CD31-positive (endothelial) cells and $\alpha$ smooth muscle actin ( $\alpha \mathrm{SMA}) /$ vimentinpositive vascular SMC/pericytes (Fig. 2iv c, d, e, f, g and h). In the myometrium, but not fibroid, CTNNB1 immunostaining was significantly increased in association with blood vessels regardless of cycle stage
(Fig. 2iii). Furthermore, fibroid-associated blood vessel CTNNB1 staining was also significantly stronger compared with myometrial SMC (twofold increase) in both proliferative and secretory phases (Fig. 2iii). Semiquantitative scoring demonstrated weaker CTNNB1 staining in myometrial SMC compared with fibroid tissue (SMC and blood vessels) in both proliferative and secretory phases, with some samples appearing nearly negative (Fig. 2iii and iv).

Double IHC for NR2F2 and CTNNB1 demonstrated that the two proteins are co-localised to the same cell types, but mostly within different sub-cellular compartments (Fig. 3). NR2F2 was localised to the nucleus, whereas CTNNB1 protein was found within the cytoplasm, cellular membrane and occasionally on the nucleus. When nuclear co-localisation of NR2F2 and 


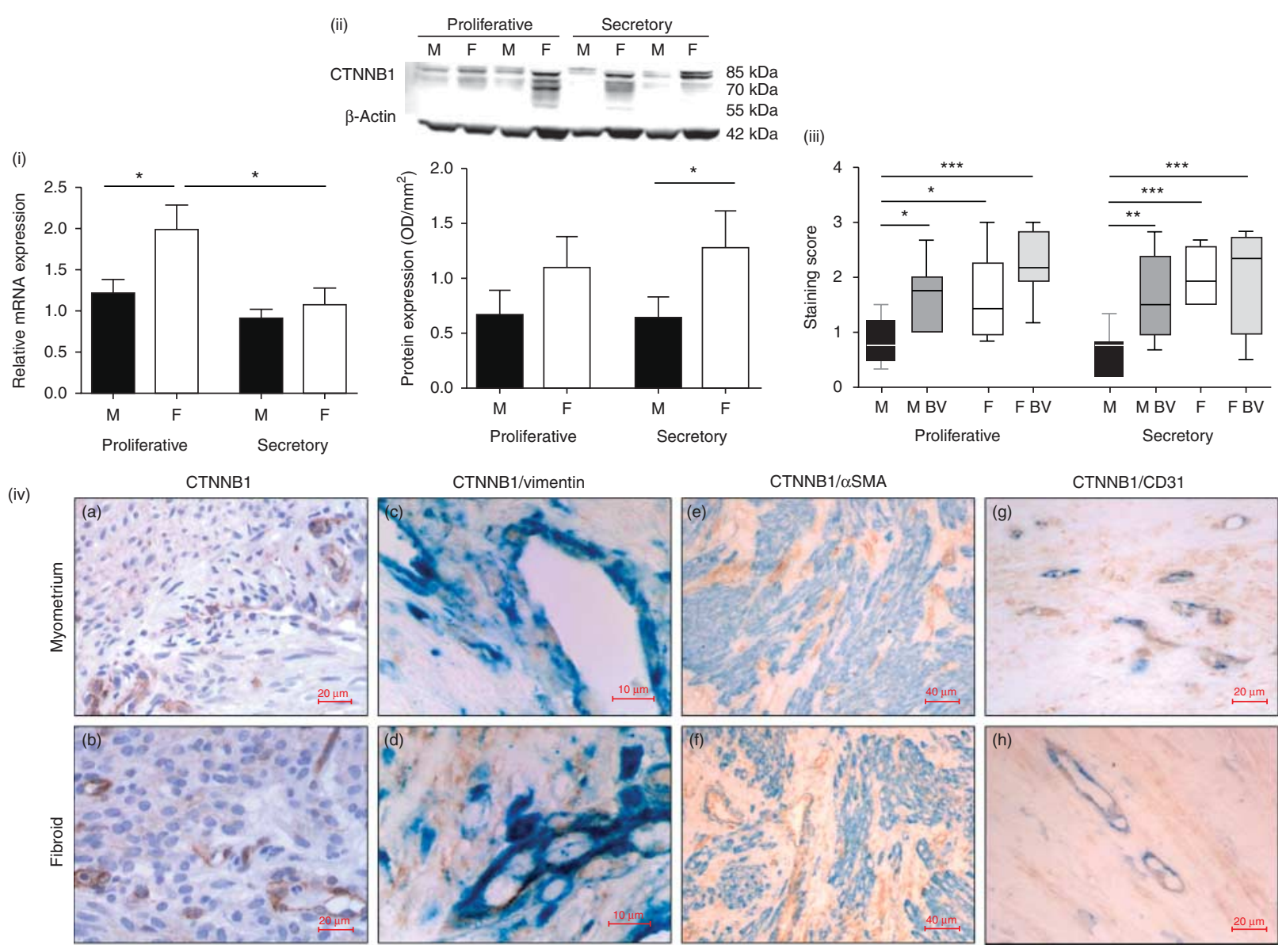

Figure 2 Differential CTNNB1 expression in uterine myometrium and fibroids. Relative expression of CTNNB1 mRNA (i) and protein (ii) in uterine fibroids (F) compared with matched normal myometrium (M) tissue. IHC (iv) for CTNNB1 was performed on paired F and M samples. M and F were grouped according to proliferative and secretory phases of the menstrual cycle with $n=10$ paired $\mathrm{M}$ and $\mathrm{F}$ samples included per phase. IHC micrographs are representative only and do not depict cycle stage. Single CTNNB1 myometrial (a) and fibroid (b) staining (brown). Double IHC for CTNNB1 (brown) plus vimentin (Vim; blue) for $\mathrm{M}(\mathrm{c})$ and $\mathrm{F}(\mathrm{d})$, CTNNB1 (blue) and $\alpha \mathrm{SMA}$ (brown) for M (e) and F ( $\mathrm{f}$ ) and CTNNB1 (brown) and CD31 (endothelial marker; blue) for $\mathrm{M}(\mathrm{g})$ and $\mathrm{F}(\mathrm{h})$. Semiquantitative scoring of CTNNB1 protein staining intensity is displayed for $\mathrm{M}$ and $\mathrm{F}$ smooth muscle cells/stroma and also for MBV and FBV (iii). Scoring were performed on $n=12$ paired $\mathrm{M}$ and $\mathrm{F}$ samples from the proliferative phase and $n=11$ paired $\mathrm{M}$ and $\mathrm{F}$ samples from the secretory phases of the menstrual cycle. Relative protein expression of CTNNB1 is displayed as the mean optical density $\left(\mathrm{OD} / \mathrm{mm}^{2}\right) \pm$ S.E.M. All other data are presented as the mean \pm S.E.M., with statistical difference denoted by $* * * P<0.001, * * P<0.01$ and $* P<0.05$.

CTNNB1 was observed, it was limited to strongly stained perivascular cells (Fig. 3, arrows).

\section{Progesterone and $R A$ in combination regulate NR2F2 mRNA expression in myometrial cells}

We investigated whether progesterone, RA or combined progesterone + RA treatment could regulate NR2F2 and CTNNB1 mRNA expression in myometrial and fibroid primary cells (P0). Following culture and treatment, cycle stage-associated differences in NR2F2 and CTNNB1 gene expression were no longer observed (data not shown), and therefore, women included in primary culture experiments in the remainder of this investigation were from mixed cycle stage. $P R$ mRNA expression was confirmed in P0 myometrial and fibroid cells (relative $P R$ mRNA expression in myometrial cells
$1.25 \pm 0.21$ (range 0.26-2.27) and fibroid cells 2.68 \pm 0.58 (range 0.57-4.58)). When progesterone and RA were combined, NR2F2 mRNA expression was significantly down-regulated in myometrial cells compared with controls $(P<0.05)$ and compared with myometrial cells treated with progesterone alone $(P<0.05)$ (Fig. $4 \mathrm{i})$. RA or progesterone treatment alone did not significantly alter myometrial NR2F2 mRNA expression compared with controls. Furthermore, progesterone and/or RA exposure did not affect NR2F2 mRNA expression in fibroid cells (Fig. 4i). Similarly, expression of CTNNB1 was not significantly altered by progesterone, RA or combined progesterone+RA treatment in both cell types (Fig. 4ii). There was a large degree of NR2F2 and $C T N N B 1$ gene expression variability in response to progesterone/RA between myometrial, but not fibroid, samples (Fig. 4i and ii). 


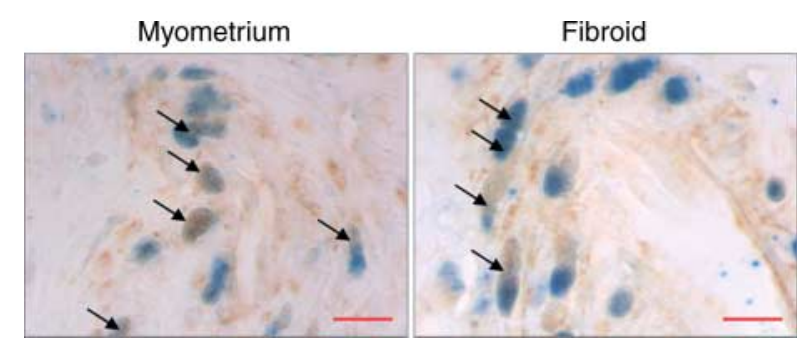

Figure 3 Co-localisation of NR2F2 and CTNNB1 in myometrial and fibroid tissues. Double IHC for NR2F2 (blue) and CTNNB1 (brown) was performed on $n=10$ paired myometrium and fibroid samples.

Scale bar $=10 \mu \mathrm{m}$. Arrows indicate NR2F2 and CTNNB1 co-localised to the nucleus.

\section{SHH does not regulate NR2F2 or CTNNB1 expression in myometrial and fibroid cells}

We also investigated whether the SHH pathway was involved in regulating $N R 2 F 2$ and CTNNB1 mRNA expression in myometrial and fibroid primary cells (PO). To confirm that the $\mathrm{SHH}$ pathway was active in myometrial and fibroid primary cell cultures, we examined the mRNA expression of two SHH-responsive genes, glioma-associated oncogene homologue 1 (GLI1) and Patched1 (PTCH1), following treatment with $\mathrm{SHH}$ $\mathrm{CM}$. In support of an active $\mathrm{SHH}$ pathway in myometrial and fibroid cultured cells, both GLI1 and PTCH1 genes were significantly up-regulated after $\mathrm{SHH}$ CM treatment in both cell types $(P<0.05$; Fig. 5i). In contrast, the mRNA expression of NR2F2 and CTNNB1 was unaltered by treatment with $\mathrm{SHH} C \mathrm{CM}$ in both myometrial and fibroid cells (Fig. 5ii).

\section{Discussion}

Although a large number of genes are differentially expressed in fibroids compared with myometrium (Tsibris et al. 2002, Skubitz \& Skubitz 2003, Arslan et al. 2005, Luo et al. 2005a, 2005b, Zaitseva et al. 2006, Dimitrova et al. 2009), it is likely that most of these changes occur as a consequence of the fibroids' presence and do not cause fibroid development. We have targeted NR2F2 and CTNNB1 in this study based on their significant potential for a causal role in uterine fibroid pathophysiology (Petit et al. 2007, Tanwar et al. 2009). We report that NR2F2 and CTNNB1 levels are altered in human uterine fibroids and that both proteins display strong blood vessel localisation in myometrial and fibroid tissues. We show that in cultured myometrial cells, NR2F2 mRNA expression is reduced by progesterone/RA treatment. We also demonstrate that while the $\mathrm{HH}$ pathway is active in primary myometrial and fibroid cells, $\mathrm{SHH}$ does not regulate NR2F2 or CTNNB1 mRNA expression.

This study demonstrated decreased expression of NR2F2 in uterine fibroids, consistent with our previous work (Zaitseva et al. 2008). Fibroid-associated decrease in NR2F2 expression was evident at the mRNA and protein level (statistically significant for IHC, but not western blotting). There are several reasons why NR2F2 mRNA and protein levels may not match, including differences in turnover dynamics, post-translational or -transcriptional regulation and targeted degradation. Reduced NR2F2 expression was specific to the secretory

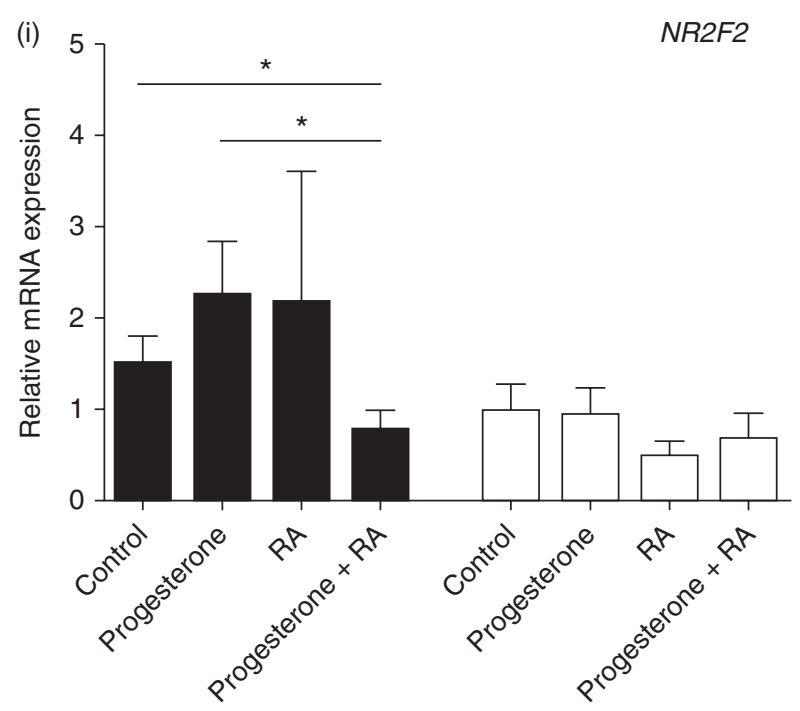

Myometrial cells $\quad$ Fibroid cells

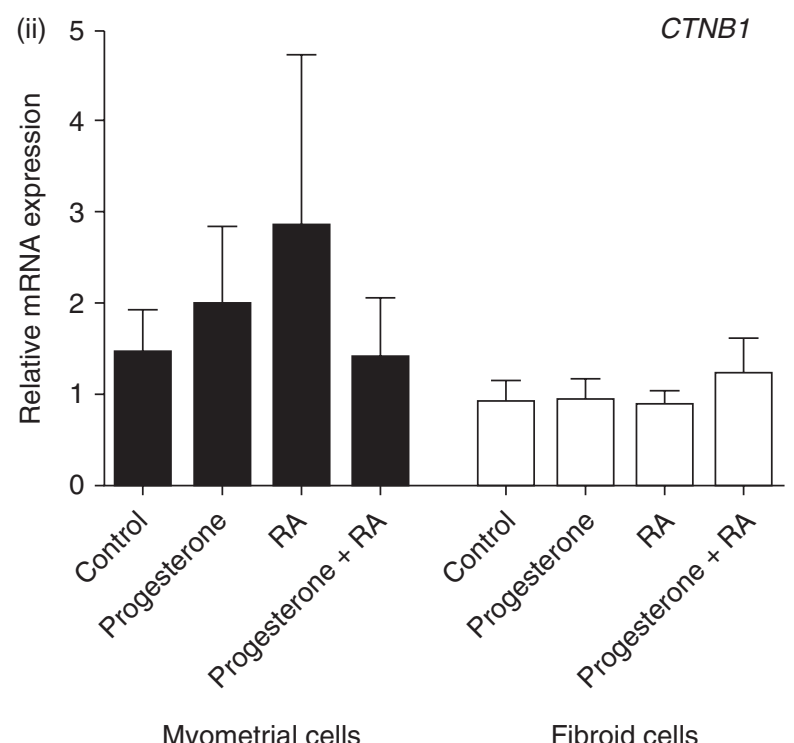

Figure 4 Progesterone and RA regulate $N R 2 F 2$ gene expression in myometrial but not fibroid primary culture. Primary cultures of paired $\mathrm{M}$ and $\mathrm{F}$ cells $(\mathrm{PO})$ were treated for $24 \mathrm{~h}$ with vehicle control, progesterone, RA or progesterone $+\mathrm{RA}(n=5)$. Relative mRNA expression of NR2F2 (i) and CTNNB1 (ii) is displayed for $\mathrm{M}$ and $\mathrm{F}$ cultures. Data are displayed as mean \pm s.E.M., with significant differences denoted by $* P<0.05$. 

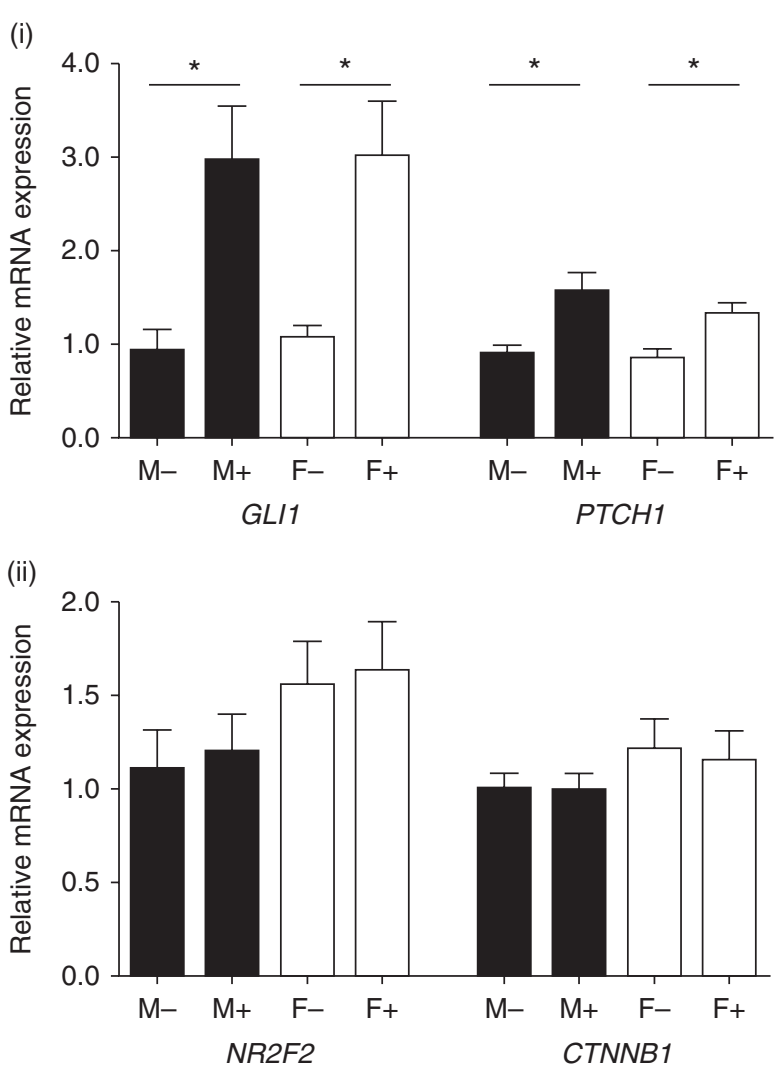

Figure $5 \mathrm{SHH}$ pathway does not regulate NR2F2 or CTNNB1 mRNA expression. Primary cultures of paired $\mathrm{M}$ and $\mathrm{F}$ cells $(\mathrm{P} 0)$ were treated for $24 \mathrm{~h}$ with $\mathrm{SHH}$ incubation media $(n=6)$. Relative mRNA expression of specific SHH target genes, PTCH1 and GLI1 (i), is displayed for M and $\mathrm{F}+/-\mathrm{SHH}$ incubation media. Relative mRNA expression of NR2F2 and CTNNB1 (ii) is also displayed for $\mathrm{M}$ and $\mathrm{F}+/-\mathrm{SHH}$ incubation media. Data are displayed as mean \pm S.E.M., with significant differences denoted by $* P<0.05$.

stage of the menstrual cycle. Menstrual cycle stageassociated expression of NR2F2 has not been reported previously in the uterus. However, granulosa cells from normal cycling ovaries also display cycle stage-specific NR2F2 expression, with highest expression occurring in dominant follicles (Sato et al. 2003). Altered NR2F2 expression has been demonstrated in several cancers, including lymphoma (Enjuanes et al. 2011), leukaemia (Bullinger et al. 2010), breast cancer (Tommasi et al. 2009) and salivary gland carcinoma (Bell et al. 2011). Ablation of NR2F2 in mice directs the plasticity of mesenchymal cells towards the myoblast lineage (resulting in increased muscle mass; Xie et al. 2011); these observations support the notion that tumourrelated down-regulation of NR2F2 expression could play a role in fibroid growth as uterine fibroids are mesenchymally derived tumours.

With respect to CTNNB1, we observed increased protein and mRNA expression in fibroids compared with paired myometrium. Cycle stage differences in CTNNB1 expression were observed for mRNA (proliferative stage) and protein (western blot; secretory stage); however, IHC demonstrated increased $\beta$-catenin expression in fibroids during both proliferative and secretory phases, relative to myometrium. A fibroid-associated increase in CTNNB1 confirms microarray data by us and others (Luo et al. 2005a, Zaitseva et al. 2006). Aberrant expression/ mutations of CTNNB1 leading to increased nuclear localisation, and enhanced Wnt signalling, have been observed in endometrial carcinoma (Fukuchi et al. 1998, Saegusa \& Okayasu 2001, Moreno-Bueno et al. 2002, Kim et al. 2009). Non-uterine smooth muscle tumours similarly demonstrate increased CTNNB1 expression and nuclear translocation during proliferation or predisposing tumour development (Gosens et al. 2010, van Veelen et al. 2011). While we did not analyse differences in nuclear expression of CTNNB1, we did observe nuclear localisation in both myometrium and fibroids. Compelling evidence for a role of CTNNB1 in the development of uterine fibroids comes from a mouse model with constitutive activation of CTNNB1 (Tanwar et al. 2009). These mice develop uterine smooth muscle tumours resembling fibroids and endometrial stromal sarcoma-like lesions with $100 \%$ penetrance (Tanwar et al. 2009). Evidence from this mouse model in combination with the data generated in our study strongly implicate an up-regulation of CTNNB1 in having a central role in fibroid development.

Both NR2F2 and CTNNB1 demonstrated increased blood vessel-specific expression patterns in myometrium and fibroid tissues. Fibroids commonly have altered vasculature suggestive of impaired angiogenesis (reviewed by Fleischer et al. (2008)), including reduced vascular density and a lack of muscular layers surrounding vessels (Casey et al. 2000, Aitken et al. 2006). In mice, full or partial deletion of NR2F2 or CTNNB1 is lethal due to malformations of the large vessels and microvasculature (Pereira et al. 1999, Cattelino et al. 2003, Dejana 2010). We propose that the decreased expression of $N R 2 F 2$ in fibroids may lead to altered expression of angiogenic factors, such as angiopoietin-1 (Qin et al. 2010, Jeansson et al. 2011, Saharinen \& Alitalo 2011), which may contribute to the altered and immature vasculature of uterine fibroids. CTNNB1 is also fundamental to maintenance of normal vasculature (Cattelino et al. 2003). Quiescent blood vessels maintain low basal Wnt/CTNNB1 signalling; however, in the presence of disease, CTNNB1 signalling is up-regulated (reviewed by van de Schans et al. (2008)). Therefore, both NR2F2 and CTNNB1 have the capacity to regulate genes involved in blood vessel maintenance. Given the strong expression of NR2F2 and CTNNB1 in myometrial and fibroid vasculature, it is possible that these proteins may play a role in the altered phenotype of fibroid blood vessels.

We examined potential regulators of $N R 2 F 2$ and CTNNB1 expression in vitro and report that treatment with progesterone and RA (in combination) significantly 
decreases NR2F2 expression in myometrial but not fibroid primary cells. While the precise mechanisms are unclear, fibroid cells demonstrate an inability to interact with or recognise progesterone and RA and respond like normal adjacent myometrium. $P R$ expression reduces in myometrial and fibroid cultures; however, as demonstrated previously (Zaitseva et al. 2006), we confirmed that $P R$ is expressed in measurable amounts in $\mathrm{PO}$ myometrium and fibroid cell. There is also evidence from human myometrial primary and explant cultures that PR functionality is retained in vitro (Cermik et al. 2001, Dong et al. 2003). In contrast, CTNNB1 expression in myometrial and fibroid cells were not affected by progesterone and/or RA treatments. Several studies report that members of the Wnt signalling pathway, but not CTNNB1 itself, are regulated by progesterone in human endometrial cells (Tulac et al. 2006, Catalano et al. 2007, Kane et al. 2008). Therefore, the progesterone-associated effects on the CTNNB1 pathway in the endometrium may be cell-type specific and not affect myometrial cells. In vivo we saw secretory-stage differential regulation of NR2F2 expression, when progesterone levels are physiologically highest; however, in culture, progesterone only affected NR2F2 expression in the presence of RA. We have previously demonstrated that components of the RA pathway are significantly altered in fibroids (Zaitseva et al. 2007) and that many of the genes that are regulated by RA are differentially expressed between myometrium and fibroids (Zaitseva et al. 2008). NR2F2 is an orphan receptor, and in an attempt to identify its endogenous ligand, Kruse et al. (2008) showed that high concentrations of RA (10-100 times physiological levels) up-regulated NR2F2 transcriptional activity. Fibroids are reported to have higher levels of all-trans RA compared with myometrium (Tsibris et al. 1999). NR2F2 also directly interacts with RARs and effects the expression of target genes via the RA pathway (Pinaire et al. 2000, Hubert et al. 2010, Prahalad et al. 2010, Vilhais-Neto et al. 2010). Alone, progesterone has been found to have little effect on NR2F2 activity (Kruse et al. 2008). Indirectly, however, NR2F2 expression can be modulated by progesterone in the mouse uterus, through paracrine mechanisms involving epithelial cells and the $\mathrm{HH}$ pathway (Lee et al. 2006b, Simon et al. 2009b). Upstream regulators of $N R 2 F 2$ expression must also be considered, including brahma-related gene 1 (SMARCA4 (BRG1)), which is a tumour suppressor that normally promotes NR2F2 expression (Davis et al. 2013) and is induced by synthetic retinoids (Xu et al. 2010). Interestingly, studies on SMARCA4 conditional homozygous mutants show that these mice develop uterine tumours (Serber et al. 2012). Overall, our findings raise the possibility that decreased levels of $N R 2 F 2$, as a consequence of interacting progesterone and RA, may contribute to aberrant RA signalling in uterine fibroids.
To the best of our knowledge, we report for the first time that the $\mathrm{HH}$ pathway is functional in uterine fibroids and myometrium. The $\mathrm{HH}$ pathway is important in many normal and abnormal cellular functions, including embryonic development, stem cell proliferation and cancer genesis (reviewed by Varjosalo \& Taipale (2008), Choi et al. (2011), Harris et al. (2011) and Park et al. (2011)). The HH pathway is also crucial to the development of reproductive tract (Franco \& Yao 2012), uterine function (Takamoto et al. 2005, Lee et al. 2006a, Petit et al. 2007) and uterine malignancies (Feng et al. 2007, Kim et al. 2009). Despite evidence for a role of $\mathrm{HH}$ in the uterus, and our results demonstrate that the $\mathrm{HH}$ pathway is active in cultured myometrial and fibroid cells; NR2F2 and CTNNB1 mRNA expressions were not affected by $\mathrm{SHH}$ treatment. Previously, NR2F2 was found to be induced by $\mathrm{HH}$ in uterine stroma in mice (Matsumoto et al. 2002, Simon et al. 2009b) and a SHH response element has been identified in the NR2F2 promoter (Krishnan et al. 1997). Conversely, another study failed to identify $\mathrm{NR} 2 \mathrm{~F} 2$ as a $\mathrm{SHH}$ target in pluripotent mesenchymal cells using microarray technology (Ingram et al. 2002). Also using mouse models, $\mathrm{SHH}$ (and Gli3) have been implicated in Wnt/CTNNB1 pathway activation and formation of the genital tract (Ulloa et al. 2007, Miyagawa et al. 2009). In the endometrium, the $\mathrm{HH}$ pathway functions via epithelialmesenchymal cross talk (Matsumoto et al. 2002, Simon et al. 2009b). Our results suggest that mechanisms of $\mathrm{HH}$ signalling differ between endometrium and myometrium and that NR2F2 and CTNNB1 are not $\mathrm{HH}$-activated targets in myometrium and fibroids.

Both NR2F2 and CTNNB1 have been implicated in tumour progression via EMT mechanisms. For example, aberrant expression of NR2F2 has been associated with induction of dedifferentiation, cell migration and angiogenesis (reviewed by Boudot et al. (2011)), while CTNNB1 is considered to be an early signalling molecule in EMT (Zhou et al. 2012). In uterine disease, EMT is mainly associated with endometrial disorders including adenomyosis (Chen et al. 2010) and endometrial cancer (Montserrat et al. 2012). In renal fibrogenesis, more than one third of disease-related fibroblasts come from epithelia involved in EMT (Kalluri \& Neilson 2003). We have shown that fibroblasts constitute a major cellular component of uterine fibroids (Zaitseva et al. 2007; SJ Holdsworth-Carson, M Zaitseva, BJ Vollenhoven \& PAW Rogers, unpublished observations). Therefore, we suggest that $N R 2 F 2$ and $C T N N B 1$ may play roles in EMT-mediated development of some uterine fibroids, in particular fibroid fibroblasts.

In conclusion, we demonstrate aberrant expression of NR2F2 and CTNNB1 in uterine fibroids compared with normal myometrium. In particular, we identified that these proteins display strong blood vessel-specific localisation, indicating that they may play a role in angiogenesis or vessel homoeostasis, a process that is 
often abnormal in uterine fibroids. With respect to their regulation, we show that the $\mathrm{HH}$ pathway does not regulate $N R 2 F 2$ or $C T N N B 1$ expression, while $N R 2 F 2$ expression was regulated by combined RA and progesterone, two factors with important roles in uterine fibroid pathology. Further work is required to fully clarify the roles of NR2F2 and CTNNB1 in fibroid development. However, our work shows that these proteins exhibit differential expression and dysregulation in association with fibroids, and given that both NR2F2 and CTNNB1 are critical to many aspects of uterine biology, these genes are worthy of further consideration as potential causal factors in uterine fibroid development.

\section{Declaration of interest}

The authors declare that there is no conflict of interest that could be perceived as prejudicing the impartiality of the research reported.

\section{Funding}

This work was supported by National Health and Medical Research Council (606613 to P A W Rogers and B J Vollenhoven).

\section{Acknowledgements}

The authors would like to thank Dr Premila Paiva for help with IHC quantification, and Nancy Taylor, Frances Walker, Lee Ann Mahoney and Lorraine Thompson for tissue collection.

\section{References}

Aitken E, Khaund A, Hamid SA, Millan D \& Campbell S 2006 The normal human myometrium has a vascular spatial gradient absent in small fibroids. Human Reproduction 21 2669-2678. (doi:10.1093/humrep/ del220)

Arslan AA, Gold LI, Mittal K, Suen T-C, Belitskaya-Levy I, Tang M-S \& Toniolo P 2005 Gene expression studies provide clues to the pathogenesis of uterine leiomyoma: new evidence and a systematic review. Human Reproduction 20 852-863. (doi:10.1093/humrep/ deh698)

Bell A, Bell D, Weber RS \& El-Naggar AK 2011 CpG island methylation profiling in human salivary gland adenoid cystic carcinoma. Cancer $\mathbf{1 1 7}$ 2898-2909. (doi:10.1002/cncr.25818)

Boudot A, Dily FL \& Pakdel F 2011 Involvement of COUP-TFs in cancer progression. Cancer 3 700-715. (doi:10.3390/cancers3010700)

Bullinger L, Ehrich M, Dohner K, Schlenk RF, Dohner H, Nelson MR \& Van den Boom D 2010 Quantitative DNA methylation predicts survival in adult acute myeloid leukemia. Blood 115 636-642. (doi:10.1182/blood-2009-03-211003)

Byers S, Pishvaian M, Crockett C, Peer C, Tozeren A, Sporn M, Anzano M \& Lechleider R 1996 Retinoids increase cell-cell adhesion strength, $\beta$-catenin protein stability, and localization to the cell membrane in a breast cancer cell line: A role for serine kinase activity. Endocrinology 137 3265-3273. (doi:10.1210/en.137.8.3265)

Casey R, Rogers PAW \& Vollenhoven BJ 2000 An immunohistochemical analysis of fibroid vasculature. Human Reproduction 15 1469-1475. (doi:10.1093/humrep/15.7.1469)

Catalano RD, Critchley HO, Heikinheimo O, Baird DT, Hapangama D, Sherwin JR, Charnock-Jones DS, Smith SK \& Sharkey AM 2007
Mifepristone induced progesterone withdrawal reveals novel regulatory pathways in human endometrium. Molecular Human Reproduction 13 641-654. (doi:10.1093/molehr/gam021)

Cattelino A, Liebner S, Gallini R, Zanetti A, Balconi G, Corsi A, Bianco P, Wolburg H, Moore R, Oreda B et al. 2003 The conditional inactivation of the $\beta$-catenin gene in endothelial cells causes a defective vascular pattern and increased vascular fragility. Journal of Cell Biology 162 1111-1122. (doi:10.1083/jcb.200212157)

Cermik D, Karaca M \& Taylor HS 2001 HOXA10 expression is repressed by progesterone in the myometrium: differential tissue-specific regulation of HOX gene expression in the reproductive tract. Journal of Clinical Endocrinology and Metabolism 86 3387-3392. (doi:10.1210/jc.86.7. 3387)

Chen Y-J, Li H-Y, Huang C-H, Twu N-F, Yen M-S, Wang P-H, Chou T-Y, Liu Y-N, Chao K-C \& Yang M-H 2010 Oestrogen-induced epithelialmesenchymal transition of endometrial epithelial cells contributes to the development of adenomyosis. Journal of Pathology 222 261-270. (doi:10.1002/path.2761)

Choi SS, Omenetti A, Syn WK \& Diehl AM 2011 The role of hedgehog signaling in fibrogenic liver repair. International Journal of Biochemistry \& Cell Biology 43 238-244. (doi:10.1016/j.biocel.2010. 10.015)

Chu K, Boutin J-M, Breton C \& Zingg HH 1998 Nuclear orphan receptors COUP-TFII and Ear-2: presence in oxytocin-producing uterine cells and functional interaction with the oxytocin gene promoter. Molecular and Cellular Endocrinology 137 145-154. (doi:10.1016/ S0303-7207(97)00241-4)

Davis RB, Curtis CD \& Griffin CT 2013 BRG1 promotes COUP-TFII expression and venous specification during embryonic vascular development. Development 140 1272-1281. (doi:10.1242/dev.087379)

Day Baird D, Dunson DB, Hill MC, Cousins D \& Schectman JM 2003 High cumulative incidence of uterine leiomyoma in black and white women: ultrasound evidence. American Journal of Obstetrics and Gynecology 188 100-107. (doi:10.1067/mob.2003.99)

Dejana E 2010 The role of Wnt signaling in physiological and pathological angiogenesis. Circulation Research 107 943-952. (doi:10.1161/CIRCRESAHA.110.223750)

Dimitrova IK, Richer JK, Rudolph MC, Spoelstra NS, Reno EM, Medina TM \& Bradford AP 2009 Gene expression profiling of multiple leiomyomata uteri and matched normal tissue from a single patient. Fertility and Sterility 91 2650-2663. (doi:10.1016/j.fertnstert.2008.03.071)

Dong YL, Wimalawansa S \& Yallampalli C 2003 Effects of steroid hormones on calcitonin gene-related peptide receptors in cultured human myometrium. American Journal of Obstetrics and Gynecology 188 466-472. (doi:10.1067/mob.2003.42)

Enjuanes A, Fernandez V, Hernandez L, Navarro A, Bea S, Pinyol M, Lopez-Guillermo A, Rosenwald A, Ott G, Campo E et al. 2011 Identification of methylated genes associated with aggressive clinicopathological features in mantle cell lymphoma. PLOS ONE 6 e19736. (doi:10.1371/journal.pone.0019736)

Fahnenstich J, Nandy A, Milde-Langosch K, Schneider-Merck T, Walther $\mathbf{N}$ \& Gellersen B 2003 Promyelocytic leukaemia zinc finger protein (PLZF) is a glucocorticoid- and progesterone-induced transcription factor in human endometrial stromal cells and myometrial smooth muscle cells. Molecular Human Reproduction 9 611-623. (doi:10.1093/molehr/ gag080)

Farquhar CM \& Steiner CA 2002 Hysterectomy rates in the United States 1990-1997. Obstetrics and Gynecology 99 229-234. (doi:10.1016/ S0029-7844(01)01723-9)

Feng YZ, Shiozawa T, Miyamoto T, Kashima H, Kurai M, Suzuki A, Ying-Song J \& Konishi I 2007 Overexpression of hedgehog signaling molecules and its involvement in the proliferation of endometrial carcinoma cells. Clinical Cancer Research 13 1389-1398. (doi:10.1158/1078-0432.CCR-06-1407)

Fleischer R, Weston GC, Vollenhoven BJ \& Rogers PAW 2008 Pathophysiology of fibroid disease: angiogenesis and regulation of smooth muscle proliferation. Best Practice \& Research. Clinical Obstetrics \& Gynaecology 22 603-614. (doi:10.1016/j.bpobgyn.2008.01.005)

Franco HL \& Yao HH 2012 Sex and hedgehog: roles of genes in the hedgehog signaling pathway in mammalian sexual differentiation. Chromosome Research 20 247-258. (doi:10.1007/s10577-011-9254-z) 
Fukuchi T, Sakamoto M, Tsuda H, Maruyama K, Nozawa S \& Hirohashi S $1998 \beta$-Catenin mutation in carcinoma of the uterine endometrium. Cancer Research 58 3526-3528.

Gargett CE, Bucak K, Zaitseva M, Chu S, Taylor N, Fuller PJ \& Rogers PA 2002 Estrogen receptor- $\alpha$ and $-\beta$ expression in microvascular endothelial cells and smooth muscle cells of myometrium and leiomyoma. Molecular Human Reproduction 8 770-775. (doi:10.1093/ molehr/8.8.770)

Garry R 2005 The future of hysterectomy. International Journal of Obstetrics and Gynaecology 112 133-139. (doi:10.1111/j.1471-0528.2004.00431.x)

Gosens R, Baarsma HA, Heijink IH, Oenema TA, Halayko AJ, Meurs H \& Schmidt M 2010 De novo synthesis of $\{\beta\}$-catenin via H-Ras and MEK regulates airway smooth muscle growth. FASEB Journal 24 757-768. (doi:10.1096/fj.09-136325)

Harris LG, Samant RS \& Shevde LA 2011 Hedgehog signaling: networking to nurture a promalignant tumor microenvironment. Molecular Cancer Research 9 1165-1174. (doi:10.1158/1541-7786.MCR-11-0175)

Hochman E, Castiel A, Jacob-Hirsch J, Amariglio N \& Izraeli S 2006 Molecular pathways regulating pro-migratory effects of hedgehog signaling. Journal of Biological Chemistry 281 33860-33870. (doi:10.1074/jbc.M605905200)

Hubert MA, Sherritt SL, Bachurski CJ \& Handwerger S 2010 Involvement of transcription factor NR2F2 in human trophoblast differentiation. PLoS ONE 5 e9417. (doi:10.1371/journal.pone.0009417)

Ingram WJ, Wicking CA, Grimmond SM, Forrest AR \& Wainwright BJ 2002 Novel genes regulated by sonic hedgehog in pluripotent mesenchymal cells. Oncogene 21 8196-8205. (doi:10.1038/sj.onc.1205975)

Jeansson M, Gawlik A, Anderson G, Li CJ, Kerjaschki D, Henkelman M \& Quaggin SE 2011 Angiopoietin-1 is essential in mouse vasculature during development and in response to injury. Journal of Clinical Investigation 121 2278-2289. (doi:10.1172/JCl46322)

Jeong J \& Mcmahon AP 2005 Growth and pattern of the mammalian neural tube are governed by partially overlapping feedback activities of the hedgehog antagonists patched 1 and Hhip1. Development 132 143-154. (doi:10.1242/dev.01566)

Jeong JW, Lee HS, Franco HL, Broaddus RR, Taketo MM, Tsai SY, Lydon JP \& Demayo FJ $2009 \beta$-Catenin mediates glandular formation and dysregulation of $\beta$-catenin induces hyperplasia formation in the murine uterus. Oncogene 28 31-40. (doi:10.1038/onc.2008.363)

Kalluri R \& Neilson EG 2003 Epithelial-mesenchymal transition and its implications for fibrosis. Journal of Clinical Investigation 112 1776-1784.

Kane N, Jones M, Brosens JJ, Saunders PT, Kelly RW \& Critchley HO 2008 Transforming growth factor- $\beta 1$ attenuates expression of both the progesterone receptor and Dickkopf in differentiated human endometrial stromal cells. Molecular Endocrinology 22 716-728. (doi:10.1210/me. 2007-0316)

Kim KH, Kim JM, Choi YL, Shin YK, Lee HC, Seong IO, Kim BK, Chae SW, Chung YS \& Kim SH 2009 Expression of sonic hedgehog signaling molecules in normal, hyperplastic and carcinomatous endometrium. Pathology International 59 279-287. (doi:10.1111/j.1440-1827.2009. 02366.x)

Krishnan V, Elberg G, Tsai MJ \& Tsai SY 1997 Identification of a novel sonic hedgehog response element in the chicken ovalbumin upstream promoter-transcription factor II promoter. Molecular Endocrinology 11 1458-1466. (doi:10.1210/me.11.10.1458)

Kruse SW, Suino-Powell K, Zhou XE, Kretschman JE, Reynolds R, Vonrhein C, Xu Y, Wang L, Tsai SY, Tsai MJ et al. 2008 Identification of COUP-TFII orphan nuclear receptor as a retinoic acid-activated receptor. PLoS Biology 6 e227. (doi:10.1371/journal.pbio.0060227)

Kurihara I, Lee D-K, Petit FG, Jeong J, Lee K, Lydon JP, Demayo FJ, Tsai M-J \& Tsai SY 2007 COUP-TFII mediates progesterone regulation of uterine implantation by controlling ER activity. PLoS Genetics 3 e102. (doi:10.1371/journal.pgen.0030102)

Lee K, Jeong J, Kwak I, Yu CT, Lanske B, Soegiarto DW, Toftgard R, Tsai MJ, Tsai S, Lydon JP et al. 2006a Indian hedgehog is a major mediator of progesterone signaling in the mouse uterus. Nature Genetics 38 1204-1209. (doi:10.1038/ng1874)

Lee K, Jeong J, Tsai MJ, Tsai S, Lydon JP \& Demayo FJ 2006b Molecular mechanisms involved in progesterone receptor regulation of uterine function. Journal of Steroid Biochemistry and Molecular Biology 102 41-50. (doi:10.1016/j.jsbmb.2006.09.006)
Lee DK, Kurihara I, Jeong JW, Lydon JP, Demayo FJ, Tsai MJ \& Tsai SY 2010 Suppression of ER $\alpha$ activity by COUP-TFII is essential for successful implantation and decidualization. Molecular Endocrinology $\mathbf{2 4}$ 930-940. (doi:10.1210/me.2009-0531)

Livak KJ \& Schmittgen TD 2001 Analysis of relative gene expression data using real-time quantitative PCR and the $2(-$ Delta Delta $C(\mathrm{~T}))$ method. Methods 25 402-408. (doi:10.1006/meth.2001.1262)

Luo X, Ding L, Xu J \& Chegini N 2005a Gene expression profiling of leiomyoma and myometrial smooth muscle cells in response to transforming growth factor- $\beta$. Endocrinology 146 1097-1118. (doi:10.1210/en.2004-1377)

Luo X, Ding L, Xu J, Williams RS \& Chegini N 2005b Leiomyoma and myometrial gene expression profiles and their responses to gonadotropin-releasing hormone analog therapy. Endocrinology $\mathbf{1 4 6}$ 1074-1096. (doi:10.1210/en.2004-1384)

Matsumoto H, Zhao X, Das SK, Hogan BL \& Dey SK 2002 Indian hedgehog as a progesterone-responsive factor mediating epithelial-mesenchymal interactions in the mouse uterus. Developmental Biology 245 280-290. (doi:10.1006/dbio.2002.0645)

Miyagawa S, Moon A, Haraguchi R, Inoue C, Harada M, Nakahara C, Suzuki K, Matsumaru D, Kaneko T, Matsuo I et al. 2009 Dosagedependent hedgehog signals integrated with $\mathrm{Wnt} / \beta$-catenin signaling regulate external genitalia formation as an appendicular program. Development 136 3969-3978. (doi:10.1242/dev.039438)

Mohamed OA, Jonnaert M, Labelle-Dumais C, Kuroda K, Clarke HJ, Dufort D \& Roberts RM 2005 Uterine Wnt/ $\beta$-catenin signaling is required for implantation. PNAS 102 8579-8584. (doi:10.1073/pnas. 0500612102)

Montserrat N, Mozos A, Llobet D, Dolcet X, Pons C, de Herreros AG, Matias-Guiu X \& Prat J 2012 Epithelial to mesenchymal transition in early stage endometrioid endometrial carcinoma. Human Pathology $\mathbf{4 3}$ 632-643. (doi:10.1016/j.humpath.2011.06.021)

Moreno-Bueno G, Hardisson D, Sanchez C, Sarrio D, Cassia R, Garcia-Rostan G, Prat J, Guo M, Herman JG, Matias-Guiu X et al. 2002 Abnormalities of the APC/ $\beta$-catenin pathway in endometrial cancer. Oncogene 21 7981-7990. (doi:10.1038/sj.onc.1205924)

Nei H, Saito T, Yamasaki H, Mizumoto H, Ito E \& Kudo R 1999 Nuclear localization of $\beta$-catenin in normal and carcinogenic endometrium. Molecular Carcinogenesis 25 207-218. (doi:10.1002/(SICl)10982744(199907)25:3 <207::AID-MC7 > 3.0.CO;2-4)

Noyes RW, Hertig AT \& Rock J 1950 Dating the endometrial biopsy. Fertility and Sterility $13-25$

Okolo S 2008 Incidence, aetiology and epidemiology of uterine fibroids. Best Practice \& Research. Clinical Obstetrics \& Gynaecology 22 571-588. (doi:10.1016/j.bpobgyn.2008.04.002)

Park K-S, Martelotto LG, Peifer M, Sos ML, Karnezis AN, Mahjoub MR, Bernard K, Conklin JF, Szczepny A, Yuan J et al. 2011 A crucial requirement for hedgehog signaling in small cell lung cancer. Nature Medicine 17 1504-1508. (doi:10.1038/nm.2473)

Pereira FA, Qiu Y, Zhou G, Tsai M-J \& Tsai SY 1999 The orphan nuclear receptor COUP-TFII is required for angiogenesis and heart development. Genes and Development 13 1037-1049. (doi:10.1101/gad.13.8.1037)

Petit FG, Jamin SP, Kurihara I, Behringer RR, Demayo FJ, Tsai MJ \& Tsai SY 2007 Deletion of the orphan nuclear receptor COUP-TFII in uterus leads to placental deficiency. PNAS 104 6293-6298. (doi:10.1073/pnas. 0702039104)

Pinaire J, Hasanadka R, Fang M, Chou WY, Stewart MJ, Kruijer W \& Crabb D 2000 The retinoid $X$ receptor response element in the human aldehyde dehydrogenase 2 promoter is antagonized by the chicken ovalbumin upstream promoter family of orphan receptors. Archives of Biochemistry and Biophysics 380 192-200. (doi:10.1006/abbi.2000.1915)

Prahalad P, Dakshanamurthy S, Ressom H \& Byers SW 2010 Retinoic acid mediates regulation of network formation by COUP-TFII and VE-cadherin expression by TGF $\beta$ receptor kinase in breast cancer cells. PLoS ONE 5 e10023. (doi:10.1371/journal.pone.0010023)

Qin J, Chen X, Xie X, Tsai M-J \& Tsai SY 2010 COUP-TFII regulates tumor growth and metastasis by modulating tumor angiogenesis. PNAS 107 3687-3692. (doi:10.1073/pnas.0914619107)

Saegusa M \& Okayasu I 2001 Frequent nuclear $\beta$-catenin accumulation and associated mutations in endometrioid-type endometrial and ovarian carcinomas with squamous differentiation. Journal of Pathology 194 59-67. (doi:10.1002/path.856) 
Saharinen P \& Alitalo K 2011 The yin, the yang, and the angiopoietin-1. Journal of Clinical Investigation 121 2157-2159. (doi:10.1172/ JCI58196)

Sato Y, Suzuki T, Hidaka K, Sato H, Ito K, Ito S \& Sasano H 2003 Immunolocalization of nuclear transcription factors, DAX-1 and COUP-TF II, in the normal human ovary: correlation with adrenal 4 binding protein/steroidogenic factor-1 immunolocalization during the menstrual cycle. Journal of Clinical Endocrinology and Metabolism 88 3415-3420. (doi:10.1210/jc.2002-021723)

van de Schans VAM, Smits JFM \& Blankesteijn WM 2008 The Wnt/frizzled pathway in cardiovascular development and disease: Friend or foe? European Journal of Pharmacology 585 338-345. (doi:10.1016/j.ejphar. 2008.02.093)

Serber DW, Rogala A, Makarem M, Rosson GB, Simin K, Godfrey V, vanDyke T, Eaves CJ \& Bultman SJ 2012 The BRG1 chromatin remodeler protects against ovarian cysts, uterine tumors, and mammary tumors in a lineage-specific manner. PLOS ONE 7 e31346. (doi:10.1371/journal. pone.0031346)

Simon L, Spiewak KA, Ekman GC, Kim J, Lydon JP, Bagchi MK, Bagchi IC, Demayo FJ \& Cooke PS 2009a Stromal progesterone receptors mediate induction of Indian hedgehog (IHH) in uterine epithelium and its downstream targets in uterine stroma. Endocrinology 150 3871-3876. (doi:10.1210/en.2008-1691)

Simon L, Spiewak KA, Ekman GC, Kim J, Lydon JP, Bagchi MK, Bagchi IC, Demayo FJ \& Cooke PS 2009b Stromal progesterone receptors mediate induction of Indian hedgehog $(\mathrm{IHH})$ in uterine epithelium and its downstream targets in uterine stroma. Endocrinology 150 3871-3876. (doi:10.1210/en.2008-1691)

Skubitz KM \& Skubitz APN 2003 Differential gene expression in leiomyosarcoma. Cancer 98 1029-1038. (doi:10.1002/cncr.11586)

Takamoto N, Kurihara I, Lee K, Demayo FJ, Tsai MJ \& Tsai SY 2005 Haploinsufficiency of chicken ovalbumin upstream promoter transcription factor II in female reproduction. Molecular Endocrinology 19 2299-2308. (doi:10.1210/me.2005-0019)

Tanwar PS, Lee HJ, Zhang L, Zukerberg LR, Taketo MM, Rueda BR \& Teixeira JM 2009 Constitutive activation of $\beta$-catenin in uterine stroma and smooth muscle leads to the development of mesenchymal tumors in mice. Biology of Reproduction 81 545-552. (doi:10.1095/biolreprod. 108.075648)

Tesco G, Kim TW, Diehlmann A, Beyreuther K \& Tanzi RE 1998 Abrogation of the presenilin $1 / \beta$-catenin interaction and preservation of the heterodimeric presenilin 1 complex following caspase activation. Journal of Biological Chemistry 273 33909-33914. (doi:10.1074/jbc. 273.51.33909)

Tommasi S, Karm DL, Wu X, Yen Y \& Pfeifer GP 2009 Methylation of homeobox genes is a frequent and early epigenetic event in breast cancer. Breast Cancer Research 11 R14. (doi:10.1186/bcr2233)

Treloar SA, Do K-A, O'connor VM, O'connor DT, Yeo MA \& Martin NG 1999 Predictors of hysterectomy: An Australian study. American Journal of Obstetrics and Gynecology 180 945-954. (doi:10.1016/ S0002-9378(99)70666-6)

Tsibris JC, Porter KB, Jazayeri A, Tzimas G, Nau H, Huang H, Kuparadze K, Porter GW, O'Brien WF \& Spellacy WN 1999 Human uterine leiomyomata express higher levels of peroxisome proliferator-activated receptor $\gamma$, retinoid $X$ receptor $\alpha$, and all-trans retinoic acid than myometrium. Cancer Research 59 5737-5744.

Tsibris JC, Segars J, Coppola D, Mane S, Wilbanks GD, O'Brien WF \& Spellacy WN 2002 Insights from gene arrays on the development and growth regulation of uterine leiomyomata. Fertility and Sterility $\mathbf{7 8}$ 114-121. (doi:10.1016/S0015-0282(02)03191-6)

Tulac S, Overgaard MT, Hamilton AE, Jumbe NL, Suchanek E \& Giudice LC 2006 Dickkopf-1, an inhibitor of Wnt signaling, is regulated by progesterone in human endometrial stromal cells. Journal of Clinical Endocrinology and Metabolism 91 1453-1461. (doi:10.1210/jc.20050769)

Ulloa F, Itasaki N \& Briscoe J 2007 Inhibitory Gli3 activity negatively regulates $W n t / \beta$-catenin signaling. Current Biology 17 545-550. (doi:10.1016/j.cub.2007.01.062)

Varjosalo M \& Taipale J 2008 Hedgehog: functions and mechanisms. Genes and Development 22 2454-2472. (doi:10.1101/gad.1693608)

van Veelen $W$, Le $\mathbf{N H}$, Helvensteijn $W$, Blonden $L$, Theeuwes $M$, Bakker ERM, Franken PF, van Gurp L, Meijlink F, van der Valk MA et al. $2011 \beta$-Catenin tyrosine 654 phosphorylation increases Wnt signalling and intestinal tumorigenesis. Gut 60 1204-1212. (doi:10.1136/gut.2010.233460)

Vilhais-Neto GC, Maruhashi M, Smith KT, Vasseur-Cognet M, Peterson AS, Workman JL \& Pourquie O 2010 Rere controls retinoic acid signalling and somite bilateral symmetry. Nature 463 953-957. (doi:10.1038/ nature08763)

Wang Y, van der Zee M, Fodde R \& Blok LJ 2010 Wnt/ $\beta$-catenin and sex hormone signaling in endometrial homeostasis and cancer. Oncotarget 1 674-684.

Wechter ME, Stewart EA, Myers ER, Kho RM \& Wu JM 2011 Leiomyoma-related hospitalization and surgery: prevalence and predicted growth based on population trends. American Journal of Obstetrics and Gynecology 205 492e1-492e5. (doi:10.1016/j.ajog. 2011.07.008)

Wei Q, Levens ED, Stefansson L \& Nieman LK 2010 Indian hedgehog and its targets in human endometrium: menstrual cycle expression and response to CDB-2914. Journal of Clinical Endocrinology and Metabolism 95 5330-5337. (doi:10.1210/jc.2010-0637)

Xie X, Qin J, Lin SH, Tsai SY \& Tsai MJ 2011 Nuclear receptor chicken ovalbumin upstream promoter-transcription factor II (COUP-TFII) modulates mesenchymal cell commitment and differentiation. PNAS 108 14843-14848. (doi:10.1073/pnas.1110236108)

Xu YZ, Heravi M, Thuraisingam T, Di Marco S, Muanza T \& Radzioch D 2010 Brg-1 mediates the constitutive and fenretinide-induced expression of SPARC in mammary carcinoma cells via its interaction with transcription factor Sp1. Molecular Cancer 9 210. (doi:10.1186/14764598-9-210)

Zaitseva M, Vollenhoven BJ \& Rogers PAW 2006 In vitro culture significantly alters gene expression profiles and reduces differences between myometrial and fibroid smooth muscle cells. Molecular Human Reproduction 12 187-207. (doi:10.1093/molehr/gal018)

Zaitseva M, Vollenhoven BJ \& Rogers PA 2007 Retinoic acid pathway genes show significantly altered expression in uterine fibroids when compared with normal myometrium. Molecular Human Reproduction 13 577-585. (doi:10.1093/molehr/gam040)

Zaitseva M, Vollenhoven BJ \& Rogers PA 2008 Retinoids regulate genes involved in retinoic acid synthesis and transport in human myometrial and fibroid smooth muscle cells. Human Reproduction 23 1076-1086. (doi:10.1093/humrep/den083)

Zhou B, Liu Y, Kahn M, Ann DK, Han A, Wang H, Nguyen C, Flodby P, Zhong Q, Krishnaveni MS et al. $2012 \beta$-Catenin/CBP-dependent regulation of TGF- $\beta$-mediated epithelial-mesenchymal transition (EMT) by SMAD3. Journal of Biological Chemistry 287 7026-7038. (doi:10.1074/jbc.M111.276311)

Received 5 March 2013

First decision 8 April 2013

Revised manuscript received 19 May 2013

Accepted 23 May 2013 